\author{
MoniKa Menke \\ Palacký University Olomouc, Czech Republic \\ (D) https://orcid.org/0000-0002-2814-2524
}

\title{
Plenary Council in the Czech Republic (1997-2005)
}

\begin{abstract}
This article analyses the preparation, process and conclusions of the Plenary Council of the Catholic Church in the Czech Republic held in 1997-2005. The Plenary Council was one of the few manifestations of the collegiality of the Czech Church, because the diocesan synods are not used here as a tool. The Decree on convocation of the Assembly was announced by the Czech and Moravian bishops on 5 July 1997 in Velehrad. The council was also an opportunity for priests and laity in the country to realise their responsibility for the Church and the co-responsibility of the Church for the condition of society. The Council had a preparatory phase (1997-2003), a stage of the 1st Session (July 2003), and a second phase of the Session (July 2005) where the project was completed and followed by the process of post-conciliar steps. Three final messages were the immediate output from the Second Plenary Session: the Message of the Council to the Public; the Message of the Council to the Believers of the Catholic Church and the Message of the Council to Christians in the Czech Republic. The resulting document was published in 2007 under the title The Life and Mission of Christians in the Church and the World. It was a document of a pastoral nature, in no way of a normative nature (no rules were actually adopted despite the work of the commission and the proposals). The Czech situation is described as "post-Christian missionary territory" there and - estimated the course of the conciliar process and of the Council itself - as an introduction of more intensive implementation of synodality in the Czech Church.

Keywords: Plenary Council in the Czech Republic, synodality, collegiality, pastoral care, Commission for the Particular Law, Czech Bishops' Conference, the life and mission of Christians in the Church and the world
\end{abstract}


Introduction and terminology

Synodality is an ambiguous term that has not as yet been defined by the Magisterium. Generally speaking, it is a certain attribute of Church communion, which includes its structure, collegial act and coexistence. From the point of view of Canon Law, elements of synodality may be found especially in the case of collegiate legislative bodies. The term has also been used in its indirect sense for denoting collegial acts of advisory bodies at different levels of government of the Church. The concept of synodality is based on a conciliar understanding of the Church as a community and its transfer into an actual pastoral situation. The structures of Church government include both singular elements (pope, bishop) and collegial elements (councils, synods) as a specific form of cooperation. In the case of this model, however, it is neither a dictatorship nor a democracy. The Church does not understand democracy in the sense of the current political notion (i.e. as a division of power among people, exercise of will of the majority of them and at the same time the protection of human rights, as well as the rights of minorities). It justifies such an understanding through its aim of protecting supernatural reality and by the fact that it concerns not only the human community, but it also overlaps beyond eternity. These overlapping facts cannot be voted on and cannot be changed by the "will of the people." The development of democratic societies has significantly influenced the "practical" life of the Church, in particular learning how to act and discuss issues together more often, or, as the case may be, making decisions together. Synodality can thus be described as the active involvement of the hierarchy in matters related to the world Church and the involvement of all believers in the matters of a particular Church, that is, a feature that is supposed to deepen the relationship between the community and authority, as well as unity and diversity at all levels. ${ }^{1}$

${ }^{1}$ From the point of view of etymology, the Greek word $\sigma v v o \delta 1 \alpha$ denoted a group of travelers, a group of pilgrims traveling together. By combining the prefix ovv (with, together) and the root odos, which has more meanings (way, walk, way of life) we reach synodality, which means a property of the community, including its structure, collegial act and coexistence. The term synodality $(\sigma v v o \delta 1 \alpha)$ cannot be found in Scripture, but the collegial act of the Apostles can be seen, for example, in the addition of Apostle Matthew to the apostolic circle instead of Judas - Acts of the Apostles (hereinafter referred to as Acts) 1:15-25; in the election of the seven deacons in Acts 6:1-7; when the apostles send Peter and John together to Samaria so that the newly baptised ones could receive the Holy Spirit - Acts 8:14-15, etc. The early Christians used the concept of $\sigma 0 v o \delta 1 \alpha$ in the sense of spiritually active, which means a common journey of members of the Church through the history of this world. Saint Irenaeus speaks of the Church as $\sigma v v \delta i \alpha \tau \omega v$ 
The concept of synodality and collegiality ${ }^{2}$ is viewed from various points of view in theology. It will be reflected differently by a pastoral theologian, an ecclesiologist, a dogmatist (in these cases mainly in the sense of "acting together") and a lawyer. A canonist views these terms from the perspective of sacred power (sacra potestas) and its applications within the existing system of church government, that is, as "joint decision-making." The Code of Canon Law of 1983 distinguishes the synod, which is only an advisory assembly in the original Latin text, and the council, which is a legislative assembly. The Code of Canons of the Eastern Churches of 1990 does not make such a distinction, because concilium is a Latin translation of the Greek term ovvodos; the designation council is used here only for an ecumenical council. This article is focused on the Czech Catholic Church, a unique project of collegiality in the Czech Church, which took place at the turn of the millennium and lasted for eight years.

\section{The current situation of the synodality in particular Churches}

The collegiate dimension of the life of the Church takes place at three basic levels of government: 1) at the level of the universal Church - as the body of bishops headed by the Pope; 2) at the level of the assembly of local Churches (provinces) with bishops ${ }^{3}$ assembled with one other and with their head (metropolitan), and 3) at the level of the local Church entrusted to the pastoral care of the bishop in the role of its shepherd. Conferences of Bishops, Church provinces and ecclesiastical regions are distinguished at the supra-diocesan level. In the framework of the Conference of Bishops, the plenary session of the Conference of Bishops is a collegial assembly, which is of a consultative nature (although some of its

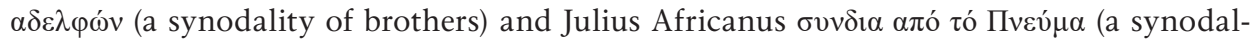
ity according to the Spirit), the Divine Liturgy of Saint John Chrysostom prays for $\sigma v v \delta 1 \alpha$

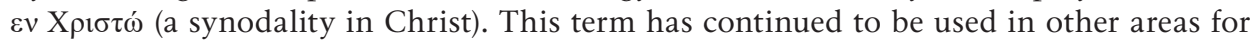
a liturgical gathering and for the Church.

2 Cf. Apostolorum Successores, 12, 23; Lumen gentium 23, Pastores gregis 26, 57, Christus Dominus 3-6.

${ }^{3}$ Historically the first synods (held at the end of the 2nd century in connection with a dispute over the date of Easter in Rome, Caesarea, Lyon, Ephesus) were of a regional character and bishops from geographically or culturally related areas gathered at them. The First Council of Nicaea (AD 325) then recommended organising provincial synods twice a year, but this practice was used more in the East. 
conclusions may be enacted either as law by individual bishops or as general degrees by the Conference of Bishops upon approval by the Holy See in cases where a rule of law is recognised for a Conference of Bishops). As concerns the councils of local (particular) Churches and the expressions of collegiality in the particular sense of the word, the Code distinguishes between the Plenary Council and the Provincial Council. ${ }^{4}$ The Plenary Council (concilium plenarium) has legislative power. It is the assembly of all the local Churches of the same Conference of Bishops which is convened by the Conference of Bishops whenever it deems it necessary or useful and upon approval by the Holy See. ${ }^{5}$ The same procedure is applied in the case of the Provincial Council if the borders of the provincial council are the same as the borders of the state. ${ }^{6}$ The Conference of Bishops establishes the place where the Plenary Synod shall be held, lays down the rules of procedure and the matters to be discussed, determines the beginning and duration of the synod, or may reschedule, postpone and terminate it. ${ }^{7}$ The president of the plenary council is elected by the Conference of Bishops and the election must be approved by the Holy See. ${ }^{8}$ As regards the participants in the plenary council, CIC/1983 distinguishes between four types of them ${ }^{9}$ : obligatory participants with a decisive vote (diocesan bishops, bishops-coadjutors, auxiliary bishops and titular bishops carrying out specific tasks assigned to them by the Holy See or the Conference of Bishops of that country $)^{10}$; 2) facultative participants with a decisive vote (other bishops, titular or emeritus ones residing in the territory of the given region $)^{11}$; 3 ) obligatory participants with an advisory vote (the general and bishop's vicars of all local Churches in the territory, major superiors of religious societies and societies of apostolic life designated for men and women by the Conference of Bishops or bishops of provinces, or, as the case may be, persons elected by all major superiors of these societies with the seat in the given territory, rectors of the Catholic and ecclesiastical universities and deans of faculties of theology and the faculty of canon law with the seat in the given territory, some rectors of the major seminars in the number stipulated in Section 2 of this canon

${ }^{4}$ In CIC/1917 there also existed the possibility of summoning a plenary council, but the bishops had to ask the Pope for permission, who then appointed a legate who would summon and preside over the council (cf. CIC/1917 c. 281).

5 Cf. CIC, c. $439 \S 1$.

${ }^{6}$ Cf. CIC, c. $439 \S 2$.

${ }^{7}$ Cf. CIC, c. 441, n. $2 ; 4$.

8 Cf. CIC, c. 441 n. 3.

9 Cf. S. Kasprzak: Wybrane zagadnienia z prawa kościelnego. Lublin-Sandomierz 2000 , p. 161.

10 Cf. CIC, c. $443 \S 1$.

${ }^{11}$ Cf. CIC, c. $443 \S 2$. 
elected by the rectors of seminars in the given territory) $)^{12}$; 4) facultative participants with an advisory vote (priests and other believers in the number which does not exceed half of the participants according to Section (\$) $1-3$ of this canon). ${ }^{13}$ Other persons may be invited to councils of the local Churches as guests if the Conference of Bishops of the plenary council or the metropolitan, together with other diocesan bishops of the province, consider it appropriate for the provincial council. ${ }^{14}$ All those invited to participate in particular councils (assemblies of local Churches) have to (debent) participate unless this is impeded by a justifiable obstacle, about which they shall inform the chairman of the council. If a justifiable obstacle does not allow the ones who have been invited to a council with a decisive vote to come to the council, they can send their representative - but that representative only has an advisory vote. ${ }^{15}$

Within the territory of the Church Province, ${ }^{16}$ the provincial coun-

12 Cf. CIC, c. $443 \S 3$.

${ }^{13}$ Cf. CIC, Article $443 \S 4$; even laity can and should also participate in the councils, which did not use to be the case in the past, except for a few cases. Cf. J. Kamas: Diecézna synoda. In: Tribunál, č. 1/2004. Spišské Podhradie 2004, p. 15: “The first mention at the level of the legislative regulation on the participation of laity in a synod is the 16th Council of Toledo (AD 693) in Can. 7. which recommends that the 'plebs' participate in the diocese so that everyone knows the decision of the provincial council. Especially after the Council of Trent (1545-1563), the particular councils and diocesan synods were exclusively clerical meetings, although even the laity with tonsure were ranked among the clergy."

${ }^{14}$ Cf. CIC, c. $443 \$ 6$.

15 Cf. CIC, c. $444 \$ 1$ a 2.

16 CIC, c. 431, \$1: "Neighboring and local churches created church provinces in the designated territory to promote joint pastoral activity in various neighboring dioceses, according to personal and local conditions and to achieve better relations among diocesan bishops." Cf. A. Hrdina: Kanonické právo. Praha 2002, pp. 239-240: "The so-called exempt diocese (not belonging to any province and immediately subordinate to the Pope) was supposed to be an exception. Circuits of ecclesiastical provinces have historical roots and it is desirable to respect the national borders (i.e., if possible, all the dioceses of one church province should lie within the borders of one and the same state). One of the dioceses of the church province, in which the seat of the metropolitan is located, is the Archdiocese while others are suffragan dioceses. In addition to the provincial council, the metropolitan has jurisdiction in the ecclesiastical province defined by law. His/her current jurisdiction is only a shadow of the power he/she used to have - he/ she is in charge of supervising compliance with faith and discipline of the Church in the suffragan dioceses, but without the right to perform visitations, with the exception of a situation when it is neglected by a suffragan and the Holy See grants him/her permission to visitation and in some cases he/she also has the right and the duty to appoint an administrator over a vacant suffragan diocese (cf. c. $436 \S 1$ n. 3). The historical title of patriarch is an honorary title in the Latin Church, which is fundamentally unrelated to any jurisdiction (the Latin Church currently has 5 patriarchates: Venice, Lisbon, Jerusalem, the East Indies and the West Indies), with the title of "patriarch of the West" being 
cil (concilium provinciale), ${ }^{17}$ which has legislative power, is the collegiate authority. It is the council of all the local Churches of the same church province, which also takes place whenever it is considered appropriate by most of the diocesan bishops of the province upon approval by the Holy See. ${ }^{18}$ The provincial assembly is chaired by the Metropolitan. ${ }^{19}$ The council is therefore not summoned while the metropolitan office is vacant. ${ }^{20}$ If the boundaries of a church province overlap with the borders of a state, the convocation of the provincial council falls under the competence of the Conference of Bishops upon approval by the Holy See. ${ }^{21}$ The status of the metropolitan is significantly emphasised here, because in relation to the provincial council, the metropolitan has the same powers as the Conference of Bishops in relation to the Plenary Council. The Metropolitan is to convene the provincial council upon agreement with the majority of the diocesan bishops of the province, ${ }^{22}$ to identify the venue of the council in the territory of the province, ${ }^{23}$ to lay down the rules of procedure and the matters for discussion, to determine the beginning and duration of the council, to reschedule it, to adjourn and to terminate it. ${ }^{24}$ The metropolitan is also supposed to chair the provincial council. If he is limited by a legal impediment, the diocesan bishop of this province (suffragan), elected by the bishops, chairs the council. ${ }^{25}$ The participants of the provincial council are the same as those of the plenary council and have similar obligations. ${ }^{26}$ In addition, the cathedral chapter of canons shall be invited to the provincial council, as well as the priestly and pastoral council of each local Church and each of them sends two of their members

restricted for the Pope. This also applies for the title of primate, which is now only a honorary title granted to some archbishops of the most important metropolises - in the past, the primate had certain rights over the metropolitans and the other bishops of a certain country, empire, or nation."

17 Cf. S. Kasprzak: Wybrane zagadnienia..., p. 159: "The Provincial Councils were introduced by the Council of Nicaea in AD 325 and by the Council of Chalcedon in 451 A.D. They should be held twice a year. The Fourth Lateran Council (1215) ordered to hold these synods once a year and the Council of Trent (1545-1563) once every three years. After the Council of Trent, however, provincial synods were convened more and more rarely. The CIC 1917 ordered them to be held at least every 20 years (cf. c. 238 CIC/1917)."

18 Cf. CIC, c. 440 \$1.

19 Cf. CIC, c. $442 \S 1$.

${ }^{20}$ Cf. CIC, c. $440 \S 2$.

${ }^{21}$ Cf. CIC, c. $440 \S 1$ and $439 \S 2$.

${ }^{22}$ CIC, c. 442 § 1 n. 1.

${ }^{23}$ CIC, c. $442 \S 1$ n. 2.

${ }^{24}$ CIC, c. $442 \S 1$ n. 3 .

${ }^{25}$ CIC, c. $442 \S 2$.

${ }^{26}$ Cf. CIC, c. $443-444 \S 1$. 
who are determined by a collegial act (collegialiter!) - they only have an advisory vote. ${ }^{27}$

The aims and tasks of councils of local Churches (i.e. the provincial council and the plenary council) are similar: the local Church council tries to meet the pastoral needs of the people of God in its territory, it has the power of governance, especially the legislative power (potestas regiminis praesertim legislativa) and in accordance with the general law of the Church. It may determine what it considers appropriate for growth of faith, organisation of common pastoral action, regulation of morals and common ecclesiastical discipline which is to be observed, promoted and protected. ${ }^{28}$ Its aim is to have pastoralism, carried out through the legislative process, flourish. When a particular council ends, the president is supposed to ensure that all acts of the council be sent to the Holy See. Decrees issued by a council are not to be promulgated until the Holy See has reviewed them (recognitio). It is up to the council itself to define the manner of promulgation of the decrees and the time when the promulgated decrees are to become effective. ${ }^{29}$ Particular councils (provincial and plenary ones) can also be included among the committees with a manifestation of collegiality (i.e. where the collegiality of bishops is partially manifested as well). Similarly, in some cases, decisions of Conferences of Bishops may also be included in this group. ${ }^{30}$ On a territory of an ecclesiastical region, ${ }^{31}$ collegiality of bishops is also manifested in the form of a meeting of the bishops of an ecclesiastical region. Although only a mee ing (conventus) to promote cooperation and joint pastoral work in such a territory, this meeting does not have the power of a Conference of Bishops (and therefore less legislative power) unless the Holy See grants it in a special way. ${ }^{32}$ In CIC/1983, one can implicitly encounter an indefinite institution (at the level of a church province), which is not specified in detail. The Code refers to it as a meeting of bishops of a province (conventus episcoporum provinciae)..$^{33}$ The Code

${ }^{27}$ Cf. CIC, c. $443 \S 5$ - this element of synodality can be classified among other manifestations of synodality in the Church.

${ }^{28}$ Cf. CIC, c. 445.

29 Cf. CIC, c. 446.

${ }^{30}$ Cf. J. Duda: Náčrt právnej ekleziológie. Spišské Podhradie 2002 , p. 94.

${ }^{31} C I C$, c. 433 § 1 : "If it seems advantageous, especially in nations where particular churches are more numerous, the Holy See can combine neighboring ecclesiastical provinces into ecclesiastical regions at the request of the conference of bishops." This is, in fact, a new legal regulation $=$ a region, unlike in the case of church provinces in these areas (which can also be established by the Holy See as legal entities cf. 433 §2), it is not a regular part of the horizontal structure of the government of the Church.

32 Cf. CIC, c. 434.

33 Cf., for example, c. $952 \S 1$ CIC, which states that the amount of offering to apply the mass is determined by the Provincial Council or the meeting of bishops of an ecclesiastical region. 
does not say anything more detailed about this meeting ${ }^{34}$ and one can only conclude that it is a formally unconstituted meeting of bishops from a province. This is why the decisions of this meeting are not binding for diocesan bishops, unless the Code provides otherwise in individual cases. There may arise, however, situations that require bishops of a province to adopt the same and uniform pastoral procedure for certain problems. ${ }^{35}$

Despite the wishes of the Second Vatican Council, ${ }^{36}$ the significance of particular councils, which used to be the main sources of particular normative formation and guardians of the ecclesiastical discipline, has in fact decreased in connection with the outflow of former metropolitan powers, both towards the centre (the Holy See) and towards the bishops. Paradoxically, the before non-existent institutions of the Conferences of Bishops have also significantly weakened the importance of particular councils, which has also been reflected in the low frequency of their convocation. ${ }^{37}$

\section{Preparation of the Plenary Council of the Czech Republic}

Although the Second Vatican Council has called for organisation of plenary councils and for renewal of synodic elements in the Church, these instruments are rarely used in the Czech environment. The Czech Bishops' Conference (established in the spring of 1990 as a Czechoslovak one, when it had two parts acting autonomously: Bohemian-Moravian and Slovak), became independent after the dissolution of Czechoslovakia in 1993. As far as diocesan collegiate activities are concerned, there exist the following advisory bodies: councils in a diocese (priestly, pastoral, and economic), devices of the diocesan curia, the Dean's Conference of Priests and councils in parishes. The most significant synodic activity of the Bohemian and Moravian Churches was the convocation and negotiation of the Plenary Council in the Czech Republic.

Dr. Miloš Raban was engaged in the initial coordination and preparation of the Plenary Council in the Czech Republic as secretary during the preparatory stage, spiritus movens, of this work. ${ }^{38}$ In January 1996, the

${ }^{34}$ For this reason, it is also not mentioned in Table 1 - the scheme of control of the Catholic Church following the Latin liturgy.

${ }^{35}$ Cf. J. Duda: Náčrt právnej ekleziológie. Spišské Podhradie 2002, , p. 196.

${ }^{36}$ Cf. ChD, p. 36

37 Cf. A. Hrdina: Kanonické právo. Praha 2002, p. 241.

${ }^{38} \mathrm{He}$ was devoted to this activity to such an extent that this present work could not have come to being without him. He described the conciliar process in the publica- 
bishops stated that they would summon the plenary council because it was impossible to summon diocesan synods for the application of the conclusions of the Second Vatican Council in the Czech Church. The preparatory committee of the council was composed of the Board, the Secretariat, six sections (an organisational, thematic, analytical, pastoral, information, and spiritual one) and its components. The holding of the Plenary Council in the Czech Republic was approved by the Holy See upon a Decree of 25 October 1996. The Decree on convocation of the Assembly was announced by the Czech and Moravian bishops on 5 July 1997 in Velehrad. At the same time, according to the episcopate, the decades of spiritual renewal of the nation established during the era of totalitarianism, was completed. The council was also an opportunity for priests and laity in the country to become aware of their responsibility for the Church and the co-responsibility of the Church for the condition of society. The Secretariat of the Preparatory Commission of the Plenary Council established the Rules of Procedure (approved in October 1997) as well as the materials for the conciliar bees. Websites were created where all the materials of the Council were collected (snem.cirkev.cz), which are accessible up to the present. ${ }^{39}$ The preparatory phase lasted for six years and was focused on formulating specific questions which the Church should answer (by gathering proposals both from clergy and laity). The entire council was held in 1997-2005 and was divided into a preparatory phase, the first-stage session (July 2003) followed by the second-stage session (July 2005), where the project was completed and the process of post-conciliar steps. So-called conciliar small groups were founded (as of summer 1998) to enable discussions, with their activities being particularly predominant in the preparatory phase (1997-2003). The small groups could be attended by any interested members of the laity and clergy and were supposed to a place for meeting and sharing. These small groups were created at bishoprics, deans' offices and vicariates, faculties of theology, priestly seminars, parishes, religious institutes and other associations of the Christian faithful, where it was possible to nominate an animator (who wrote down the results of the discussion of the bee and passed it through the moderator to the preparatory committee of the council) and create a bee. The bees worked according to pre-prepared materials (essentially a discussion of documents of the Second Vatican Council). Several hundred bees were created, some of them, at the initiative of "the people," some upon "regulation of church adminis-

tion Plenary Council in the Czech Republic, Renewal of Synodality, published in Prague in 2000.

${ }^{39}$ Czech Bishops' Conference - Plenary Council of the Czech Republic: Preparatory Commission. Online at https://www.cirkev.cz/archiv/030221-pripravna-komise-ple narniho-snemu-katolicke-cirkve-v-cr-ukoncila-svou-cinnost (accessed 29.11.2018). 
trator" (the latter ones were usually quickly disintegrated). An average bee took place five times a year with a number of ten people. Dr. Raban then states that "at the conciliar stage, bees will comment on the drafts which are a matter of discussion and their reactions will be taken into account in the final resolution." 40 Unfortunately, there was minimal feedback to the conciliar bees (the notes were not adequately elaborated at the level of a diocese or the entire Church of the Czech Republic). The final version of the work of the conciliar bees was made accessible for consultation in January 1998. The documents were, however, so disparate that it was impossible to create a coherent text out of them.

\section{Course of the Plenary Council in the Czech Republic}

The first meeting of the Plenary Council took place on 6-12 July 2003 in Velehrad. ${ }^{41}$ It was made up of eight conciliar commissions processing the stated topics of the life and mission of Christians in the Church in the country and in the world for two years; they were in permanent contact with each other and with the heads of the Council. From that time on, Dr. Jiři Kašný was the Secretary of the Council. The First Meeting of the Czech Plenary Council was attended by all the Catholic bishops in the Czech Republic, the Apostolic Nuncio in the Czech Republic Archbishop Erwin Josef Ender, all the General, Bishop and Judge Vicars, 10 representatives of women's and men's ministries, deans of theological faculties and superiors of seminars, 30 elected delegates from individual dioceses, major academic experts and the chairman of the Ecumenical Council of Churches in the Czech Republic, the Bishop of the Silesian Evangelical Church of the A.C. Vladislav Volný. The expert conciliar commissions were headed by the bishops in the function of chairpersons, while executive activities were managed by secretaries of commissions. ${ }^{42}$

${ }^{40}$ M. Raban: Sněm české katolické církve (Obnova synodality) [Plenary Council in the Czech Republic, Renewal of Synodality]. Praha 2000, Council..., p. 115. His expectations proved to be quite inadequate at this early stage, it was impossible to perform any feedback.

${ }^{41}$ Czech Bishops' Conference - Plenary Council of the Czech Republic: The plenary Council in the Czech Catholic Church in the Czech Republic was launched online at: https://www.cirkev.cz/archiv/030706-plenarni-snem-katolicke-cirkve-v-cr-zahajen (accessed 29.11.2018).

42 1. Commission for Spiritual Reading of History, Chairman Václav Malý; 2. Analytical Commission, Chairman František Radkovský; 3. Commission for Evangelisation and Missionary Work, Chairman Ladislav Hučko; 4. Commission for Priests, Deacons 
The Instrumentum laboris entitled "Let's Protect our Future" was created, this being a basic text that was discussed both in thematic groups and plenum. ${ }^{43}$ In this way, the Synod established additional tasks, which commissions needed to work on until the next session (especially in the field of missionary and evangelist activities, activities of the Church in Czech society, analysis of the situation in society and the Church, lifelong education of laity and priests, pastoral care for youth and family, care of the spiritual vocation). The Council was supposed to formulate standards for the life of the Church, and after its conclusion, it should call for diocesan synods to be held based on the possibilities of individual dioceses. The next meeting of the council was to be convened by the Czech Bishop's Conference in July 2005 and the Czech Bishops' Conference was also supposed to prepare a draft of a particular law in its legal committee.

The period between the first and second meeting: In this interim, the commissions which mainly arose from the first session worked especially in the areas of missionary and evangelising activities of the Church in the Czech society, analysis of the situation in society and the Church, lifelong education of laity and priests, taking care of young people and families and other pastoral care issues, as well as care for the spiritual profession. Conciliar commissions were established at the end of the first session of the Plenary Council in Velehrad. Throughout the following year, they worked on preparation of materials for documents related to the Second Plenary Council. In September 2004, the commissions submitted the results of their work and the text was redrafted into a document and submitted to the Bishops to study. The comments of bishops and comments by members of the Council during March at the one-day seminar of commission secretaries were subsequently incorporated and this text was presented to the plenary meeting of the Czech Bishops' Conference in April. Between the First and Second meeting, the working commission prepared additional documents for the second session, which were not subject to the vote of the Plenary Council and which were partly incorporated into the above-mentioned summary document: Statistical Documents (Analytical Commission); Wandering of the Church through Czech

and Consecrated Persons, Chairmen Josef Koukl, Vojtěch Cikrle, Jiří Pad’our; 5. Commission for the Laity, Chairman Karel Herbst; 6. Commission for Liturgy and Sacramental Pastoral Care, Chairman Josef Hrdlička; 7. Commission for Particular Law, Chairman Frantisek Lobkowicz; 8. Pastoral Commission, Chairman Dominik Duka

${ }^{43}$ Czech Bishops' Conference - Plenary Council of the Czech Republic: Press Release from the 1st Session of the Plenary Council in the Catholic Church in the Czech Republic. Online at https://www.cirkev.cz/archiv/030711-tiskova-zprava-z-1-zasedani-plena rniho-snemu-katolicke-cirkve-v-cr (accessed 29.11.2018). 
History (Commission for a Spiritual Reading of History); Laity in the World Today (Commission for the Laity).

The second session of the Plenary Council was held in Velehrad from 6 to 10 July 2005 and was attended by 117 persons: bishops, experts, guests, representatives of other Christian Churches and others who actively participated in the preparations and in the course of the Council. ${ }^{44}$ The agenda of the meeting was to discuss and ratify the text of the final document and create and approve messages of the Plenary Council. Experts and guests, including representatives of other Christian Churches, were also invited to the meeting. The conciliar text entitled "The Life and Mission of Christians" was divided, for the purpose of the meeting, into six parts (according to the subject matter as elaborated by the individual conciliar commissions): 1 - Laity in Church and Society, 2 - Priesthood, Diaconate and Consecrated Life; 3 - Liturgy and Sacramental Pastoral Care; 4 - Pastoral Care; 5 - The Missionary Role of the Church; 6 - Introduction and Conclusion. The chairman of the commission first briefly introduced part of the text (5 to 10 minutes). All the contributions to the given part were then presented in the order determined by the chairman of the Council and a discussion and voting took place.

Three final messages were the immediate output from the Second Plenary Session: the Message of the Council to the Public ${ }^{45}$; the Message of the Council to the Believers of the Catholic Church ${ }^{46}$ and the Message of the Council to Christians in the Czech Republic. ${ }^{47}$ The resulting approved conciliar text entitled "The Life and Mission of Christians in the Church and the World" was sent to the Holy See shortly after the Council and officially proclaimed after its review (recognitio). After the meeting, the chairman of the Plenary Council, Cardinal Miloslav Vlk, officially handed over the adopted conciliar resolution to the Czech Bishops' Conference. It convened the Council in 1997 and, in accord-

${ }^{44}$ Czech Bishops' Conference - Plenary Council of the Czech Republic: First and Second Plenary Session. Online at: http://snem.cirkev.cz/indexf9ec.html?menu=426 (accessed 29.11.2018).

45 Czech Bishops' Conference - Plenary Council of the Czech Republic: The message of the Council to the public. Online at: https://www.cirkev.cz/archiv/050710 -poselstvi-plenarniho-snemu-verejnosti (accessed 29.11.2018).

46 Czech Bishops' Conference - Plenary Council of the Czech Republic: The message of the Council to the Catholic believers in the Czech Republic. Online at: https:// www.cirkev.cz/archiv/050710-poselstvi-plenarniho-snemu-vericim-katolicke-cirkve-v-ces ke-republice.

47 Czech Bishops' Conference - Plenary Council of the Czech Republic: The message of the Council to the all Christians. Online at: https://www.cirkev.cz/archiv/050710 -poselstvi-plenarniho-snemu-krestanum-v-ceske-republice (accessed 29.11.2018). 
ance with the Rules of Procedure, it immediately decided to end the Plenary Council. ${ }^{48}$

The following paragraph outlines the activity of one of the commissions, the commission for a particular law from the point of view of Church Law. This commission was set up in 2003 at the first conciliar meeting, with the main Czech canonists as its members. ${ }^{49}$ The Commission focused on CIC standards, which enabled or determined what a particular authority shall decide. One of the first steps was to select and divide these canons into three areas: 1) rules of the particular law for determination of which the legislator is not specified; 2 ) rules to be determined by a respective diocesan bishop (or bishop, ordinary, prelate of the personal prelature, non-specified shepherd or superior), 3) rules to be determined by the respective Conference of Bishops. In each of the categories, it is also specified which rules are to be adopted on a mandatory basis and which ones may be adopted on an optional basis. The Commission then made a number of proposals (e.g. the duty of breviary and spiritual retreats for permanent deacons - Can. 276 Section (\$) 2 (3) and (4), the duty of Morning and Evening Prayer, five days of spiritual retreats every year). The announcement of postponement of baptism because of justified doubts about upbringing Canon 868 - a proposal to introduce an obligation to inform the parish of the domicile of such a fact if the baptism was postponed in another parish. In connection with the status of catechumens or their records, the commission proposed determination of legislative procedure at the Conference of Bishops with respect to the highly pastoral and also the technical nature of the matter, thus with regard to greater legislative flexibility of the Conference of Bishops).

No rules were actually adopted despite the work of the commission and the proposals. In addition to the meetings, the commission used mainly correspondence for communication during the first session of the Council in 2003 and after its completion. It met only a few times and rather sporadically. In the debate, it was suggested that it would be possible to take further steps and proposed standards as documents of the Council or rules.

${ }^{48}$ Czech Bishops' Conference - Plenary Council of the Czech Republic: Nuncius Causero at the conclusion of the Council. Online at: https://www.cirkev.cz/archiv/050712 -arcibiskup-causero-na-zaver-snemu (accessed 29.11.2018).

${ }^{49}$ Chairman of the Commission: Bishop František Lobkowicz, the Secretary: the official of the Prague ecclesiastical court, Jiři Svoboda. The judges of the ecclesiastical courts were members of the commission: Libor Botek, Vladimír Gajdůšek, Václav Hegr, Ignác Antonín Hrdina O. Praem, Michal Podzimek, Petr Kubíček; the lawyers Jiří Kašný and Vojtěch Kunčar; teachers of Church and Confessional Law: Damián Němec O. Praem, Stanislav Přibyl and Jiří Rajmund Tretera O. Praem. 
The Conference of Bishops could issue resolutions in the following areas: catechumenate, sermons of laity, performances of clerics on television or radio, uniform regulations for investigation of engaged couples (each diocese has its own regulations), determination of the amount of rates of court fees, administrative fees, set amount for offerings at mass, etc. There would also be a need to improve the publication of particular regulations and the resolutions of the Conference of Bishops because their investigation often involved considerable efforts.

This commission, of course, also ended with the termination of the council. Since there was a need for the bishops to have an official normative group, its activity continued in a modified form in the Commission for Particular Law of the Czech Bishops' Conference. The Commission revived its activity more recently, fulfilling specific tasks entrusted to it by the Conference of Bishops.

\section{Final document}

At the second session of the Council, several major changes were incorporated into the text submitted by the commissions, minor changes in formulation were made by the Holy See, to which the document was then sent for consideration. The resulting document was published in 2007 under the title "The Life and Mission of Christians in the Church and the World." It was a document of a pastoral nature, in no way of a normative nature. This was to start the post-conciliar process of a gradual introduction of the conclusions and experience of the Council into the life of the Czech Church. Part of this should involve the successive synods at the level of individual dioceses. The document contained 123 pages and consisted of six parts: 1) Laity in the Church and Society; 2) Priesthood, Diaconate and Consecrated Life; 3) Liturgy and Sacramental Pastoral Care; 4) Pastoral Care; 5) The Missionary Role of the Church; 6) Introduction and Conclusion.

This document attempted to describe what the current life of the Church should look like (often, of course, only interpreting and repeating the Doctrine of the Second Vatican Council). It was aimed at describing the so-called states in the Church: laity, priests and deacons, consecrated life; further liturgy (the Eucharist one, the one of individual sacraments, popular piety, especially Marian devotion) and certain issues of pastoral work. It commented on so-called categorical pastoral: youth, families, university students, the sick, seniors and others. It attempted to give impe- 
tus to the engagement of the laity in culture, family, politics, media, and social justice and describe the areas of evangelisation and missions in the Czech Church. It comments, for example, on specific pastoral questions as follows:

"One can expect over the next ten years a slight decrease in the number of active believers and a slight decrease in the number of ordained ministers of the Church" (n. 155). Restructuring of parishes would correspond with the current demographic situation and which will be necessary has been performed only in a small extent" (n. 159). Particular attention should be paid to territories where the expulsion of a large part or almost all of the population took place. These are areas where part of the population is still less than firmly rooted, where there is a weak relationship either to nature or to the architectural heritage developed by generations, where interpersonal and family relationships are well below the average level of the country and where the years of freedom in these territories have practically failed to be manifested or have been manifested in a negative way - unemployment, as well as social disorientation has increased (n. 161).

As regards family pastoral care, the Council, for example, recommended that the Diocesan Synods discuss the following incentives: a) to include pastoral care for spouses and families as an integral part of the pastoral care plans of the dioceses; b) to seek out ways to provide further education of priests, deacons and laity in the area of pastoral care for families; c) to develop various forms of pastoral care for spouses and families (family communities, pastoral care for families in a parish, pastoral care for families in special life situations, pastoral care for divorced Catholics who have remarried in a civil manner - n. 184)

The Czech situation is described as "post-Christian missionary territory," influenced not only by the overall weakening of Christianity in Western society, but also by a number of historical reasons, both from the period of the Middle Ages and Communist totalitarianism, or even from the period after November 1989 (n. 358). The document assesses the course of the conciliar process and of the Council itself as the introduction of more intensive implementation of synodality in our Church (n. 367). It also states that conciliar sessions were not just about meeting and negotiation, but that it was also a valuable opportunity for more thorough self-reflection (n. 368).

If three messages of the council are evaluated, then the message of the Council to the public only announced the conduct of this event and the co-responsibility which Catholics feel about the condition of the country. The message to Catholics was to thank everyone who had been actively involved and encourage bearing witness and active engagement in public 
Monika Menke

life. The message to other Christians made reference to the ecumenical dimension of Velehrad and the need to overcome prejudices and misunderstandings in history, emphasising the need for repentance, conversion, forgiveness and a common search for paths of authentic Christianity in the late-20th century in Europe.

\section{Feedback and impact — positive and negative ones}

Czech bishops understood the council as continuing the tradition towards to the post-conciliar Work of the Conciliar Renewal of 1968 (during the so-called Prague Spring, the political liberation of the situation in the Czech Republic, when there was a possibility to introduce the conclusions of the Second Vatican Council) as to the so-called Decades of Spiritual Renewal of the nation (the pastoral initiative of Cardinal František Tomáš and his colleagues in 1987-1997. Each year of the decades was devoted to a certain topic and one of the Czech saints or blessed was chosen for each year), as well as other activities of the laity, monastics, clergy and dissent, which led to the gift of the freedom of the Church after 1989. Based on the expectations of the bishops, the Council was supposed to create a platform and space for dialogue in the Czech Church. ${ }^{50}$ However, this was not completely achieved. Both the bishops and the laity expected a somewhat different purpose for the assembly (in addition, not quite corresponding with its notion in Canon Law - that is, the Council as a legislative assembly at the level of the territory of the Conference of Bishops). The laity expected a discussion concerning the doctrine of the Church and often unrealistic changes in church education and pastoral care. The bishops in fact initially expected a discussion related to the introduction of changes by the Second Vatican Council in the Czech Republic, which had not been up to then implemented, by discussing the basic topics of the conciliar documents in the conciliar bees, not discussing problems or possible changes in church practice). When reading the final document, it is apparent that it is largely a matter of repeating the doctrine of the Council, the Catechism of the Catholic Church and the rules of the Code of Canon Law. It was also assumed that individual diocesan synods

50 Cf. Czech Bishops' Conference - Plenary Council of the Czech Republic: Final document. Praha, 2007. Online at: http://cirkev.ecpaper.cz/zivot-a-poslani-krestanu-v-cirk vi-a-ve-svete-zaverecny-dokument-plenarniho-snemu-2007/?page=1, no. 8 (accessed 29.11. 2018). 
would gradually follow this council. It was not a regulation, but a recommendation and its convocation should be subject to the individual needs of local churches. These synods should even answer the call of the Plenary Council. Not even this has taken place, however, in the Czech Church.

The final conciliar document evaluated the conditions in the Czech Church as burdened by several facts: 1) historical traumas of longterm unresolved conflicts between the national (Czech) and the Church (Roman Catholic) identity, 2) expulsion of a significant part of Christians, especially Catholic cultural elite, into exile after the Second World War, or its violent destruction, 3) the profound religious and spiritual ignorance of most contemporary Czech citizens. ${ }^{51}$ There was a need to state the fact that Christians are a minority in Czech society and that they should therefore become the salt and light of the country to transform the present crisis into a chance for the New Evangelisation. The bishops themselves in the final document stated that the Plenary Council was summoned in order that the conclusions of the Second Vatican Council, which could not be implemented (in fact, apart from the liturgical reform, this concerned the majority of these conclusions) in the 1970s. From the beginning of the preparatory works of the Council, it had not been entirely clear what kind of assembly the bishops had in mind and after some time there began to appear remarks on the part of the canonists that the Plenary Council was actually a legislative body, not merely a "discussion group."

A number of critical comments came about in relation to this event ${ }^{52}$ : that it was a waste of time, energy and finances, which could have been used more meaningfully or that the same outcome could possibly have been achieved within an extended session of the Czech Bishops' Conference, the lack of brief and clear media presentation of the results of the Council, that the output was one long document which nobody would read, instead of a few shorter texts by topic, as was the case of the Second Vatican Council or the Synod of German Dioceses. ${ }^{53}$ In addition, there was criticism that the views of the inferior authorities had not been reflected on, that is, the votes of the conciliar bees, that although the bees were places for discussion and communion, their activity had officially been discontinued at the time of the preparation of the assembly. Examples from elsewhere, however, considered the emergence of similar groups,

${ }^{51}$ Cf. Final document, no. 256.

52 M. VAŇáč: Odbytý sněm české řimskokatolické církve. Online at: http://www.get semany.cz/node/766 (accessed 29.11.2018).

${ }^{53}$ The German Synod was established in 1969 and at eight plenary sessions in 1971-1975. It passed 18 documents and six other working texts were drawn up during the discussions of the commissions. 
this being one of the most important implications of the benefit of councils and synods. Finally, it was pointed out that the conciliar document ignored Christians of non-Catholic Churches, this having been pointed out by one of the few non-Catholic participants in the Council, the Evangelical theologian Prof. Pavel Filipi in one of his papers.

\section{Conclusions}

The Plenary Council, which took place in the Czech Church, was in fact the only official attempt to implement synodality in the Czech Lands after the Second Vatican Council. There may emerge the question as to whether this means of implementation was a genuine manifestation of synodality or instead a mere discussion forum, which was not understood all that well. Although the final text contains a number of interesting ideas, the naming of the main pastoral problems of the Church in the secularised Czech environment had failed, and paths and solutions had not been established. At present, it has been more than 10 years since the termination of the Council and the Czech Church has still not worked out its conclusions, it is not perceived as a milestone, but rather as one of the many events of the Episcopate only aimed at catching up with the post-conciliar development in the Czech environment, which was initially adopted by the laity with unrealistic expectations and which was followed by disappointment that the Council would not solve specific pastoral problems. At minimum, a certain kind of effort in relation to the first public common communication in the Church and the realisation of the specificity of the Council as a legislative instrument have been beneficial (although this aspect has not been fruitful with respect to the creation of legal rules). At least a necessary premise was implemented: to listen to one another and cooperate with each other more (hierarchies, laity and religious). It would arguably be better to first organise diocesan synods, where it would be possible to deal with the specific problems concerning the local churches and the entire nation. In smaller areas, it would also be important to learn to discuss and perceive diversity in the Church instead of the grand project of the Plenary Council (based on the possibilities given by law and historical experience). The Czech bishops therefore chose the opposite way, from the more general to the more specific, but even the preliminarily planned local synods in the individual dioceses were eventually not organised. Only the Ostrava-Opava diocese attempted an unofficial "Small Priestly Synod" in 2016, but its conclusions have not been published. 
It should be stated, however, that a reserved approach and a distrust of organising diocesan synods prevailed in the Czech Church. The majority of dioceses were unable to use this instrument (to organise a diocesan advisory synod to address specific areas of life of the local church). It is not surprising that this has been the case as the Plenary Council, which has not been perceived in a positive way, has not met the expectations of the many persons involved. There arises a question as to whether the Czech environment is so specific that there really is no need for synods, or whether this instrument has only not been used. It is apparent that especially the areas of re-evangelisation of the territories where Christianity ceased to exist, an ecumenical and often non-standard model in the area of cooperation of Church and state (healthcare chaplains, prison chaplains, military chaplains in a manner different from the CIC); or a new model of funding of churches after 2012 as concerns a specific environment. Active religiosity (based on the number of religious visitors of masses and practitioners of faith) has not decreased, but the Church in Czech society has been losing the role of the bearer of basic values. As practice has shown, even such a model of Church life is viable, although it may require greater demands on the readiness of candidates for bishops' service than in countries with a more traditional and larger Church.

\section{Bibliography}

Code of Canon Law. Latin-English edition. Canon Law Society of America, Washington, D.C, 1995

Code of Canon law (Code of Canon law 1917). Pii X Pontificis Maximi iussu digestus Benedicti Papae XV auctoritate promulgatus praefatione Emmi Petri card. Gasparri et indice analytico-alphabetico auctus. Roma: Typis Polyglottis Vaticanis, 1951.

Vatican Council II: Decree The Pastoral Office of Bishops in the Church Christus Dominus (28.10.1965). Online at: http://www.vatican.va/archive/hist_coun cils/ii_vatican_council/documents/vat-ii_decree_19651028_christus-domi nus_en.html (accessed 29.11.2018).

Vatican council II: Dogmatic Constitution of the Church Lumen Gentium (21.11.1964). Online at: http://www.vatican.va/archive/hist_councils/ii_vati can_council/documents/vat-ii_const_19641121_lumen-gentium_en.html (accessed 29.11.2018).

Congregation of Bishops: Directory for the pastoral ministry of the bishops Apostolorum Successores. Online at: http://www.vatican.va/roman_curia/ 
congregations/cbishops/documents/rc_con_cbishops_doc_20040222_apos tolorum-successores_en.html (accessed 29.11.2018).

John Paul II: Post-synodal apostolic exhortation Pastores gregis (16 October 2003). Online at http://w2.vatican.va/content/john-paul-ii/en/apost_exhor tations/documents/hf_jp-ii_exh_20031016_pastores-gregis.html (accessed 29.11.2018).

KASPRZAK, S.: Wybrane zagadnienia z prawa kościelnego. Lublin-Sandomierz 2000.

Kamas, J.: Diecézna synoda. In: Tribunál, č. 1/2004. Spišské Podhradie 2004.

DudA, J.: Náčrt právnej ekleziológie. Spišské Podhradie 2002.

Hrdina, A.: Kanonické právo. Praha 2002.

Raban, M.: Sněm české katolické církve (Obnova synodality) [Plenary Council in the Czech Republic, Renewal of Synodality]. Praha 2000.

Czech Bishops' Conference - Plenary Council of the Czech Republic.: Preparatory Commission. Online at: https://www.cirkev.cz/archiv/030221 -pripravna-komise-plenarniho-snemu-katolicke-cirkve-v-cr-ukoncila-svou -cinnost (accessed 29.11.2018).

Czech Bishops' Conference -- Plenary Council of the Czech Republic: The plenary Council in the Czech Catholic Church in the Czech Republic was launched. Online at: https://www.cirkev.cz/archiv/030706-plenarni-snem -katolicke-cirkve-v-cr-zahajen (accessed 29.11.2018).

Czech Bishops' Conference - Plenary Council of the Czech Republic: Press Release from the 1st Session of the Plenary Council in the Catholic Church in the Czech Republic. Online at: https://www.cirkev.cz/archiv/030711-tiskova -zprava-z-1-zasedani-plenarniho-snemu-katolicke-cirkve-v-cr (accessed 29.11. 2018).

Czech Bishops' Conference - Plenary Council of the Czech Republic: First and second Plenary Session. Online at: http://snem.cirkev.cz/indexf9ec. html?menu=426 (accessed 29.11.2018).

Czech Bishops' Conference - Plenary Council of the Czech Republic. The message of the Council to the public. Online at: https://www.cirkev.cz/ archiv/050710-poselstvi-plenarniho-snemu-verejnosti (accessed 29.11.2018).

Czech Bishops' Conference - Plenary Council of the Czech Republic: The message of the Council to the Catholic believers in the Czech Republic. Online at: https://www.cirkev.cz/archiv/050710-poselstvi-plenarniho-snemu-vericim -katolicke-cirkve-v-ceske-republice (accessed 29.11.2018).

Czech Bishops' Conference - Plenary Council of the Czech Republic: The message of the Council to the all Christians. Online at: https://www.cirkev. cz/archiv/050710-poselstvi-plenarniho-snemu-krestanum-v-ceske-republice (accessed 29.11.2018).

Czech Bishops' Conference - Plenary Council of the Czech Republic: Nuncius Causero at the conclusion of the Council. Online at: https://www.cirkev. cz/archiv/050712-arcibiskup-causero-na-zaver-snemu (accessed 29.11.2018).

VAŇÁč, M.: Odbytý sněm české řimskokatolické církve. [accessed on 29 November 2018] online at: http://www.getsemany.cz/node/766. 
Czech Bishops' Conference - Plenary Council of the Czech Republic: Final document. Praha 2007. Online at: http://cirkev.ecpaper.cz/zivot-a-poslani-kresta nu-v-cirkvi-a-ve-svete-zaverecny-dokument-plenarniho-snemu-2007/?page=1 (accessed 29.11.2018).

Monika Menke

Synode plénier en République tchèque (1997—2005)

Résumé

Dans le présent article, je traite de la préparation, du déroulement et des conclusions du Synode Plénier en République Tchèque, qui a eu lieu dans les années 1997-2005. Le Synode Plénier a été l'une des rares manifestations de la collégialité dans l'Église tchèque, car il n'y a pas de tradition de synodes diocésains en Tchéquie. Le décret sur la convocation du Synode Plénier a été annoncé par les évêques le 5 juillet 1997 à Velehrad. Le Synode devait aussi donner l'occasion aux prêtres et aux laïcs de prendre conscience de leur responsabilité envers l'Église et de la coresponsabilité de l'Église pour l'état de la société. Le Synode a eu une phase préparatoire (1997-2003), la première phase de la session (juillet 2003) a été suivie d'une deuxième phase de la session (juillet 2005), lors de laquelle le projet a été achevé, et enfin la phase d'étapes post-synodales. Les trois messages finaux de la deuxième phase du Synode Plénier sont: le Message du Synode à la Société, le Message aux Fidèles de l'Église catholique et le Message aux Chrétiens de la République tchèque. Le document final a été publié en 2007 sous le titre La vie et la mission des chrétiens dans l'Église et dans le monde. C'était un document à caractère pastoral, nullement normatif (contrairement aux travaux de la Commission du droit particulier et de ses propositions, aucune norme n'a finalement été adoptée). La situation tchèque a été décrite comme «un territoire de mission postchrétienne» et le déroulement du processus synodal a été vu comme une introduction à une synodalité plus complète dans l'Église tchèque.

Mots clés: Synode Plénier en République tchèque, synodalité, collégialité, aide pastorale, commission de droit particulier, conférence épiscopale tchèque, vie et mission des chrétiens dans l'Église et dans le monde

Monika Menke

Sinodo plenario nella Repubblica Ceca (1997-2005)

\section{Sommario}

In questo articolo tratterò la preparazione, il percorso e le conclusioni del Sinodo Plenario nella Repubblica Ceca, tenutosi negli anni 1997-2005. Il Sinodo Plenario è stato una delle poche manifestazioni della collegialità della Chiesa ceca, perché i sinodi diocesani non vengono indetti. Il decreto sulla convocazione del Sinodo Plenario è stato annunciato dai vescovi il 5 luglio 1997 a Velehrad. Il Sinodo doveva anche dare occa- 
sione ai sacerdoti e laici di prendere coscienza della loro responsabilità per la Chiesa e della corresponsabilità della Chiesa per lo stato della società. Il Sinodo ha avuto una fase preparatoria (1997-2003), la prima fase della sessione (luglio 2003), seguita dalla seconda fase (luglio 2005), durante la quale si è concluso il progetto, e infine le fasi post-sinodali. Tre messaggi finali della 2 a fase del Sinodo Plenario sono: il Messaggio del Sinodo alla società, il Messaggio ai fedeli della Chiesa cattolica e il Messaggio ai cristiani nella Repubblica Ceca. Il documento finale, intitolato La vita e la missione dei cristiani nella Chiesa e nel mondo, è stato pubblicato nel 2007 e. Era un documento di carattere pastorale, per nulla normativo (contrariamente all'operato del Comitato di diritto particolare e alle sue proposte, nessuna norma è stata infine adottata). La situazione ceca è stata definita come «un territorio di missione post-cristiana», e il percorso del processo sinodale è stato valutato come un'introduzione a una sinodalità più completa nella Chiesa ceca.

Parole chiave: Sinodo plenario nella Repubblica Ceca, sinodalità, collegialità, cura pastorale, commissione per il diritto particolare, conferenza episcopale ceca, vita e missione dei cristiani nella Chiesa e nel mondo 